\title{
DIFFERENCES IN PEAK BONE DENSITY BETWEEN MALE AND FEMALE STUDENTS
}

\author{
Selma CVIJETIĆ AVDAGIĆ ${ }^{1}$, Irena COLIĆ BARIĆ , Irena KESER $^{2}$, Ivana CECIĆ ${ }^{2}$ \\ Zvonimir ŠATALIĆ ${ }^{2}$, Jasminka BOBIĆ ${ }^{1}$, and Milica GOMZI ${ }^{1}$ \\ Institute for Medical Research and Occupational Health ${ }^{1}$, Laboratory for Food Chemistry and Nutrition, \\ Faculty of Food Technology and Biotechnology, University of Zagreb², Zagreb, Croatia
}

Received in June 2008

Accepted in October 2008

\begin{abstract}
As an important determinant of osteoporotic fracture risk, peak bone density tends to be higher in men than in women. The aim of this study was to see whether young men and women differed in the time and skeletal region of peak bone density. We also investigated the influence of diet and physical activity on bone mass. The study group included 51 male and 75 female students aged 19 to 25 years. Bone mineral density was measured for the spine, total femur, and the distal third of the radius using dual energy x-ray absorptiometry. Dietary data were obtained using a specially designed semiquantitative food frequency questionnaire. Bone mineral density (BMD; $\mathrm{g} \mathrm{cm}^{-2}$ ) was higher in boys than in girls at all measured sites, while bone mineral apparent density (BMAD; $\mathrm{g} \mathrm{cm}^{-3}$ ) was higher in girls. Age negatively correlated with bone mineral density in all measured sites except in the boys' spine. Sodium, protein, and fibres were nutrients that significantly correlated with bone mineral density. The study suggests that boys achieve peak bone density later than girls, and that this delay is the most prominent in the spine. In our study group, this difference could not be explained by different nutrition or the level of physical activity.
\end{abstract}

KEY WORDS: bone mineral density, diet, osteoporosis, physical activity, young people

The risk of developing symptomatic osteoporosis later in life is influenced to a large extent by the levels of peak bone mass attained in early adulthood. Peak bone mass is thought to be determined by an interaction between lifestyle and genetic factors (1-3), but the ways in which they interact with each other remain incompletely understood. Young people's lifestyle and dietary habits have changed over recent decades toward non-physical activities and fast food. Many cross-sectional and follow-up studies indicate that physical activity and calcium supplementation are beneficial through childhood and adolescence. Bone mass is higher in children and young people who are physically active (4-6). The majority of studies on children and adolescents support a positive relation between calcium intake and bone mineral density (BMD) (7-9), but there are also studies where no such association has been observed $(10,11)$.
Although the determinants of peak bone mass are well recognised, its exact timing is still controversial. It is widely accepted that most of the skeletal mass is acquired by the age of 20 , and it continues to grow slowly until the end of the third decade of life or even later. More recent studies have suggested that peak bone density is achieved by the end of adolescence $(12,13)$. Cross-sectional studies also observed that the age of attainment of peak bone mass varies with the site of bone measurement (14-15). Lin (16) proposed that peak bone mass is attained earlier at the hip than at the spine.

However, there is little data about the differences in obtaining peak density between young men and women in different skeletal regions. This study investigated whether bone mineral density in the cortical and trabecular bone of healthy student population aged 19 to 25 years had already attained 
peak bone mass, and whether it is related to lifestyle (dietary intake and physical activity).

\section{MATERIALS AND METHODS}

\section{Subjects}

The study included 51 male and 75 female students from the University of Zagreb. They were generally healthy young people, without a history of disease or therapy which could interfere with bone metabolism. They were all informed about the study protocol, which has been approved by the Ethical Committee of the Institute for Medical Research and Occupational Health. Informed consent was signed by all participants.

\section{Anthropometry and bone density measurement}

Height and weight were measured using a portable stadiometer and an electronic scale. Body mass index (BMI) was calculated as weight $(\mathrm{kg})$ divided by square height $\left(\mathrm{m}^{2}\right)$.

Areal bone mineral density (BMD; $\mathrm{g} \mathrm{cm}^{-2}$ ) was measured using dual energy X-ray absorptiometry (Lunar-Prodigy, Madison, WI). Measurements were made in the lumbar spine (L2-L4), proximal femur, and the distal third of the radius. To minimise the effect of the skeleton size, we made a volumetric, threedimensional approximation of bone density, called bone mineral apparent density (BMAD; $\mathrm{g} \mathrm{cm}^{-3}$ ) using the Katzman/Carter formula: BMAD=BMC/area ${ }^{3 / 2}$, where BMC stands for bone mineral content (17). BMD was also expressed as a T-score, that is, the number of standard deviations from the mean BMD of a control population aged between 20 and 40 years given in the manufacturer's reference values.

\section{Diet assessment}

To assess the diet, the subjects were interviewed by trained personnel using a Quantified Food Frequency Questionnaire (FFQ). The FFQ included 173 food items arranged in groups. The reference period was the previous year, and each subject was asked to recall consumption frequency ranging from once a month to once or more a day. The portion size was estimated showing photographs of food in actual size (18).

The frequency of specific nutrients was established using the U.S. Department of Agriculture (USDA) food composition tables (19). For nutrient composition of Croatian brands, we used manufacturer labels we contacted the manufacturer.
Energy and nutrient intakes were compared with Croatian reference values for vitamins and minerals (valid since 2004) (20) with Croatian Recommended Dietary Allowances (RDA) for energy and protein intake (valid since 1994) (21, 22), and with Dietary Reference Intakes (DRI) for dietary fibre, fats, carbohydrates, sodium, and potassium (23).

\section{Physical activity}

Physical activity was measured by quantifying sport and work activities: duration (months/years) and frequency (hours per week) of sport activity and intensity (moderate or hard) and frequency (hours per week) of other physical activities. Moderate physical activities included bicycle riding and, walking, and such, while hard physical activities included heavy object lifting, fitness, and such. The frequency of sport activities and the frequency of other moderate and/or hard physical activities were categorised and scored as: 1$)$ never; 2$)$ (0,5 to 1$)$ hours per week; 3 ) (2 to 3 ) hours per week; 4) (4 to 6) hours per week; 5 ) (7 to 10) hours per week; 6) (11 to 20) hours per week; 7) (21 to 30) hours per week; 8) $>31$ hours per week. The final score of physical activity was calculated for each subject by summing up years of sport activities with the frequency of moderate and hard work activity score (1 to 8). Subjects with higher final score were considered more physically active.

Table 1 Subject profile and physical activity

\begin{tabular}{lcc}
\hline & \multicolumn{2}{c}{ Mean \pm SD } \\
\cline { 2 - 3 } & $\begin{array}{c}\text { Male } \\
\text { students } \\
(\mathbf{N}=\mathbf{5 1})\end{array}$ & $\begin{array}{c}\text { Female } \\
\text { students } \\
(\mathbf{N}=\mathbf{7 5})\end{array}$ \\
\hline Age / year & $22.2 \pm 1.3$ & $22.4 \pm 0.6$ \\
Time after menarche / year & $/$ & $5.5 \pm 1.6$ \\
Height / cm & $179.4 \pm 5.6$ & $167.5 \pm 5.8^{1}$ \\
Weight / kg & $78.4 \pm 7.1$ & $59.9 \pm 6.8^{1}$ \\
Body mass index / $\mathrm{kg} \mathrm{m}^{-2}$ & $24.4 \pm 2.2$ & $21.3 \pm 1.9^{2}$ \\
Fat tissue / \% & $24.1 \pm 6.8$ & $30.8 \pm 7.2^{1}$ \\
Smoking & $(\mathrm{N}=10)$ & $(\mathrm{N}=12)$ \\
Number of cigarettes & $12.7 \pm 5.8$ & $12.5 \pm 10.6$ \\
Years & $5.0 \pm 1.7$ & $4.0 \pm 1.4^{2}$ \\
Physical activity score & $12.4 \pm 5.8$ & $7.0 \pm 3.8^{1}$ \\
\hline
\end{tabular}

${ }^{l} p<0.0001$ t-test (male vs. female students) ${ }^{2} p<0.01$ 


\section{Statistics}

The data were analysed using statistical software Statistica, version 5.0 (StatSoft Inc., Tulsa, OK). The results are shown as means \pm standard deviation (SD). The distribution of variables was tested with the Kolmogorov-Smirnov test. If the test was significant, then the hypothesis that the respective distribution was normal was rejected. Variables which were not distributed normally were log-transformed. As only five students were several months younger than 20 years (the lower limit of age range was 19.4 years), we calculated their T-scores as if they had been 20 years old. The differences between two mean values were analysed using the $t$-test. Correlation matrices were used to measure the relation between two or more variables. The association between bone mass and different predictor variables was tested with multiple regression. $\mathrm{P}$ value lower than 0.05 was considered significant.

\section{RESULTS}

The mean age of students was 22.3 years $(22.2$ years for boys and 22.4 years for girls), and it ranged from 19.4 years to 25.8 years (Table 1). Male students were significantly taller, heavier, and with greater BMI $(p<0.0001)$. However, they had a significantly lower percent of fat tissue $(p<0.0001)$ and were involved in sport activities for longer $(\mathrm{p}<0.001)$ than the girls. Twelve girls and ten boys were smokers.
The boys had a higher BMD and also a significantly higher BMC and bone area than the girls (Table 3). BMAD was higher in the girls than in the boys; the difference was particularly significant in the distal radius $(\mathrm{p}<0.0001)$. In all students, mean $\mathrm{T}$ score in the distal radius $(-0.89 \pm 0.7)$ was significantly lower than the $\mathrm{T}$ scores in other regions $[(0.66 \pm 1.07)$ spine; $(0.49 \pm 1.03)$ total femur] $(\mathrm{p}<0.0001)$. BMD and age showed negative correlation in all measured sites in girls, which was significant for the spine $(r=-$ $0.21 ; \mathrm{p}<0.05)$ and total femur $(\mathrm{r}=-0.39 ; \mathrm{p}<0.0001)$. In boys, age positively correlated with spine BMD and negatively with femur and radius BMD. These correlations, however, were not significant.

Twenty percent of male and $14.1 \%$ of female students had had fractures caused by trauma, but there was no difference in BMD between students with and without fractures. There were also no significant differences in BMD between smokers and non-smokers.

Save for vitamin E in girls (Table 2) all subject were taking nutrients within the RDA.

Multiple regression was performed to see whether any nutrient variable and physical activity predicted bone mass (Table 4). The analysis was controlled for age, height, and weight. The most significant positive predictor of bone density in girls was body weight. Dietary fibre intake negatively correlated with BMD in girls, and this correlation was significant for the spine and femur $(\mathrm{p}<0.01)$. Protein and sodium intake significantly negatively correlated with spine BMD in boys $(\mathrm{p}<0.05)$.

Table 2 Average daily energy and nutrient intake in male and female students and age-adjusted recommended levels

\begin{tabular}{lccc}
\hline \multirow{2}{*}{ Nutrition } & \multicolumn{2}{c}{ Mean \pm SD } & Fecommencieci ievei \\
\cline { 2 - 4 } & Male students & Female students & of daily intake (RDA) \\
\hline Energy / $\mathrm{kcal} \mathrm{d}^{-1}$ & $3207.4 \pm 1515.2$ & $2879.4 \pm 1449.4$ & 2200 \\
Protein / $\mathrm{g} \mathrm{d}^{-1}$ & $148.2 \pm 110.8 \mathrm{~s}$ & $109.2 \pm 43.7$ & 46 \\
Fat / $\mathrm{kcal} \mathrm{d}$ & $125.2 \pm 67.1$ & $98.2 \pm 43.1$ & 10 to 35 \\
Carbohydrates / $\mathrm{g} \mathrm{d}^{-1}$ & $369.2 \pm 152.8$ & $339.6 \pm 144.8$ & 130 \\
Dietary fiber / $\mathrm{g} \mathrm{d}^{-1}$ & $25.3 \pm 13.2$ & $26.1 \pm 12.2$ & 25 \\
Calcium / mg d & $1436.9 \pm 607.1$ & $1377.1 \pm 630.2$ & 800 \\
Sodium / $\mathrm{mg} \mathrm{d}^{-1}$ & $5903.8 \pm 3097.2$ & $4713.72 \pm 2203.2$ & 1500 to 2300 \\
Iron / $\mathrm{mg} \mathrm{d}$ & $17.4 \pm 7.9$ & $15.8 \pm 6.8$ & 14 \\
Vitamin A / $\mu \mathrm{g} \mathrm{d}^{-1}$ & $970.9 \pm 7138.7$ & $801.9 \pm 6391.8$ & 800 \\
Vitamin C / $\mathrm{mg} \mathrm{d}^{-1}$ & $222.1 \pm 237.9$ & $181.6 \pm 120.9$ & 60 \\
Vitamin E / $\mathrm{mg} \mathrm{d}^{-1}$ & $17.6 \pm 29.1$ & $9.2 \pm 5.6$ & 10 \\
Vitamin K / $\mu \mathrm{g} \mathrm{d}^{-1}$ & $181.2 \pm 148.6$ & $236.2 \pm 167.6$ & 65 \\
Vitamin B $/ \mu \mathrm{g} \mathrm{d}^{-1}$ & $9.1 \pm 7.7$ & $6.3 \pm 3.0$ & 1.0 \\
Folic acid / $\mu \mathrm{g} \mathrm{d}^{-1}$ & $626.6 \pm 286.7$ & $540.0 \pm 259.7$ & 200 \\
\hline
\end{tabular}




\section{DISCUSSION}

The results of this study suggest that there are differences in peak bone density at different skeletal regions between young male and female adults. Our male participants had a higher areal bone density in all measured sites. However, with respect to estimated volumetric bone mineral density, the difference in BMD between boys and girls could be explained by a greater increase in bone size in boys during growth. In a longitudinal study of 116 men and women, Walsh found that peak BMC velocity occurs at an age of 12.5 years in girls and 14 years in boys (24). In our study, the increase in BMC was greater than the increase in BMAD, which also points to BMAD as a more accurate parameter for the assessment of bone density in the growing skeleton. A significant negative correlation between age and bone density suggests that our students in their early twenties had already acquired peak bone density and started to lose bone. The exception was the spine in boys, since bone density at that site did not negatively correlate with age. Since it is expected that men will gain a higher peak bone density than women, we can conclude that male students had not yet achieved their peak bone density in the spine. Due to insignificant negative correlation between age and the BMD of the femur and radius, we can also conclude that boys gain peak bone density at later age than girls.

It is known that the age at which peak BMD is achieved depends on the size of the skeleton. Several authors showed that BMD at the proximal femur peaked earlier than in the spine $(13,16,25)$, which is consistent with our results. According to T scores, our students had a higher BMD of the spine and proximal femur and significantly lower BMD of the radial shaft than the reference NHANES values. Our previous results for female students suggest that young Croatian women have a lower cortical peak bone density than their American counterparts (26). These differences may be related to geographical variations in BMD worldwide, as shown in many cross-sectional, population-based studies $(27,28)$. Discrepancies in age at which peak bone density is achieved could partly be attributed to the so called "consolidation", which is a continued increase in bone mass after bone linear growth has stopped at the end of puberty (29). This process may be the result of continued increase in bone size, but also the result of a gain in volumetric bone density.

We also analysed whether the reason for the difference in peak bone density between our male

Table $3 B M D, B M C$, area, and BMAD (mean $\pm S D$ ) in the spine, neck and distal radius in male and female students

\begin{tabular}{|c|c|c|c|c|c|c|}
\hline & \multicolumn{2}{|c|}{ Spine } & \multicolumn{2}{|c|}{ Neck } & \multicolumn{2}{|c|}{ Distal radius } \\
\hline & Men & Women & Men & Women & Men & Women \\
\hline $\mathrm{BMD} / \mathrm{g} \mathrm{cm}^{-2}$ & $1.313 \pm 0.138$ & $1.305 \pm 0.139$ & $1.183 \pm 0.166$ & $1.135 \pm 0.159$ & $0.828 \pm 0.161$ & $0.783 \pm 0.109$ \\
\hline $\mathrm{BMC} / \mathrm{g}$ & $79.60 \pm 12.41^{1}$ & $69.61 \pm 13.54$ & $6.73 \pm 1.20^{2}$ & $5.24 \pm 1.05$ & $2.13 \pm 0.18^{1}$ & $2.03 \pm 0.25$ \\
\hline Area $/ \mathrm{cm}^{2}$ & $62.16 \pm 5.58^{2}$ & $53.50 \pm 7.59$ & $5.61 \pm 0.68$ & $5.13 \pm 4.61$ & $2.87 \pm 0.25^{3}$ & $2.53 \pm 0.26$ \\
\hline $\mathrm{BMAD} / \mathrm{g} \mathrm{cm}^{-3}$ & $0.166 \pm 0.018^{3}$ & $0.184 \pm 0.028$ & $0.505 \pm 0.082$ & $0.524 \pm 0.082$ & $0.189 \pm 0.037^{3}$ & $0.496 \pm 0.075$ \\
\hline
\end{tabular}

${ }^{l} p<0.01$ men vs. women ( $t$-test)

${ }^{2} p<0.001$ men vs. women ( $t$-test)

${ }^{3} p<0.0001$ men vs. women ( $t$-test)

Table 4 Significant predictors of BMD at different skeletal sites in male and female students

\begin{tabular}{|c|c|c|c|}
\hline \multirow{2}{*}{ Dependent variable } & \multirow{2}{*}{ Predictor variables } & \multicolumn{2}{|c|}{ p-level } \\
\hline & & Male students & Female students \\
\hline \multirow{4}{*}{ BMD Spine } & Body weight & 1 & $<0.001$ \\
\hline & Proteins & $<0.05$ & 1 \\
\hline & Sodium & $<0.05$ & l \\
\hline & Dietary fibre & 1 & $<0.01$ \\
\hline \multirow{2}{*}{ BMD Total femur } & Body weight & 1 & $<0.0001$ \\
\hline & Dietary fibre & 1 & $<0.01$ \\
\hline BMD Radius & Body weight & 1 & $<0.01$ \\
\hline
\end{tabular}


and female students could be any of the lifestyle factors investigated (diet and physical activity) which might vary between them. Furthermore, diet is a key determinant for the balance between bone turnover and bone mass. This study included a wide spectrum of nutrients and their possible relation to bone mass. A number studies showed a positive correlation between calcium intake and bone mass (30-32), but our results are closer to studies that do not support the theory that larger dietary calcium intake is associated with greater bone density $(10,16,33)$.

A significant negative association between dietary fibre intake and bone density in girls could be the consequence of increased urinary calcium excretion associated with increased dietary fibre intake and lower oestradiol levels in pre- and post-menopausal women $(34,35)$. This may imply that increased dietary fibre intake may adversely affect bone mass. However, the effect remains controversial, because dietary fibre may affect on calcium absorption through phytate, which is present in substantial amounts in cereals (36). Therefore, high fibre intake from a mixed diet need not adversely affect bone health , as shown by Yano et al. who found no association between dietary fibre intake and bone health (37).

The subjects in our study reported a very high intake of sodium and proteins. Over the past several decades dietary habits have shifted toward consumption of processed foods that are high in sodium. It is known that high sodium intake can accelerate calcium excretion and that hypercalciuria is a risk factor for osteoporosis (38-40). Dietary protein has also been shown to increase urinary calcium resulting from an increase in calcium bone resorption $(41,42)$. Although there is evidence of the beneficial effect of protein intake on bone health $(43,44)$, its negative correlation in our study could be the consequence of excessive protein intake in male students, which was three times the normal.

We can not explain the differences in the timing of peak bone density between the sexes with dietary factors, since all students had a satisfactory DRI, and there were no significant differences in nutrient intake between them.

A shortcoming of this study is a relatively small number of subjects, which might have led to a type I error and a false positive result. However, the aim was to establish the difference in peak bone density between men and women, not to determine the prevalence. In addition, there are several other studies on peak bone mass which have been based on a relatively small number of participants $(15,24$, $28,45,46)$.

We can conclude that peak bone density in our study population occurred before the age of twenty in most of skeletal regions. The analysis of correlation between age and bone density has shown that peak bone density occurs later in boys than girls, especially in the spine. In our study, this difference can not be explained by different diet or level of physical activity, but rather by hormonal and genetic differences. Bearing in mind that the pathogenesis of osteoporosis could be traced back to childhood or earlier, identification of the genes responsible for these effects would have a major impact on the prediction of peak bone mass and prognosis of the disease.

\section{Acknowledgement}

This work was supported by the Ministry of Science, Education and Sports, Republic of Croatia (grant no. 0220222411-2409 "Effects of general and work environment on musculo-skeletal system").

\section{REFERENCES}

1. McGuigan FEA, Murray L, Gallagher A, Davey-Smith G, Neville CE, Van't Hof R, Boreham C, Ralston SH. Genetic and Environmental Determinants of Peak Bone Mass in Young Men and Women. J Bone Mineral Res 2002;17:12739.

2. Kelly PJ, Eisman JA, Sambrook PN. Interaction of genetic and environmental influences on peak bone density. Osteoporos Int 1990;1:56-60.

3. Krall EA, Dawson-Hughes B. Heritable and life-style determinants of bone mineral density. J Bone Mineral Res 1993;8:1-9.

4. Sinaki M, Wahner HW, Bergstralh EJ, Hodgson SF, Offord KP, Squires RW, Swee RG. Three-year controlled, randomized trial of the effect of dose-specified loading and strengthening exercises on BMD of spine and femur in nonathletic, physically active women. Bone 1996;19:23344.

5. Slemenda C W, Miller JZ, Hui SL, Reister TK, Johnston CC Jr. Role of physical activity in the development of skeletal mass in children. J Bone Mineral Res 1991;6:1227-33.

6. Neville CE, Murray LJ, Boreham CAG, Gallagher AM, Twisk J, Robson PJ, Savage JM, Kemper HCG, Ralston SH, Smith GD. Relationship between physical activity and bone mineral status in young adults: the Northern Ireland Young Hearts Project. Bone 2002;30:792-8.

7. Matkovic V, Goel PK, Badenhop-Stevens NE, Landoll JD, Li B, Ilich JZ, Skugor M, Nagode LA, Mobley SL, Ha EJ, Hangartner TN, Clairmont A. Calcium supplementation and bone mineral density in females from childhood to young adulthood: a randomized controlled trial. Am J Clin Nutr 2005;81:175-88. 
8. Wallace LS, Ballard JE. Lifetime physical activity and calcium intake related to bone density in young women. $\mathrm{J}$ Women Health Gend Based Med 2002;11:389-98.

9. Bonjour JP, Carrie AL, Ferrari S, Clavien H, Slosman D, Theintz G, Rizzoli R. Calcium enriched foods and bone mass growth in prepubertal girls: a randomised, double-blind, placebo-controlled trial. J Clin Invest 1997;99:1287-94.

10. McCulloch RG, Bailey DA, Houston CS, Dodd BL. Effects of physical activity, dietary calcium intake and selected lifestyle factors on bone density in young women. Can Med Assoc J 1990;142:221-7.

11. Cvijetić S, Colić Barić I, Bolanča S, Jureša V, Dekanić Ožegović D. Ultrasound bone measurement in children and adolescents; correlation with nutrition, puberty, anthropometry and physical activity. J Clin Epidemiol 2003;56:591-7.

12. Theintz G, Buchs B, Rizzoli R, Slosman D, Clavien H, Sizonenko PC, Bonjour JP. Longitudinal monitoring of bone mass accumulation in healthy adolescents: evidence for a marked reduction after 16 years of age at the levels of lumbar spine and femoral neck in female subjects. J Clin Endocrinol Metab 1992;75:1060-5.

13. Matkovic V, Jelic T, Wardlaw GM, Ilich JZ, Goel PK, Wright JK, Andon MB, Smith KT, Heaney RP. Timing of peak bone mass in Caucasian females and its implication for the prevention of osteoporosis. J Clin Invest 1994;93:799-808.

14. Recker RR, Davies KM, Hinders SM, Heaney RP, Stegman MR, Kimmel DB. Bone gain in young adult women. J Am Med Assoc 1992;268:2403-8.

15. Henry YM, Fatayerji D, Eastell R. Attainment of peak bone mass at the lumbar spine, femoral neck and radius in men and women: relative contributions of bone size and volumetric bone mineral density. Osteopor Int 2004;15:263-73.

16. Lin YC, Lyle RM, Weaver CM, McCabe LD, McCabe GP, Johnston CC, Teegarden D. Peak spine and femoral neck bone mass in young women. Bone 2003;32:546-53

17. Katzman DK, Bachrach LK, Carter DR, Marcus R. Clinical and anthropometric correlates of bone mineral acquisition in healthy adolescent girls. J Clin Endocrinol Metab 1991;73:1332-9.

18. Hess MA. Portion Photos of Popular Foods. Chicago (IL): American Dietetic Association; 1997.

19. U.S. Department of Agriculture, Agricultural Research Service: USDA Nutrient Database for Standard Reference, Release 15, 2002. [displayed 23 September 200] Available at http://www.nal.usda.gov/fnic/foodcomp/Data/SR15/sr15. html.

20. Ministarstvo zdravstva i socijalne skrbi Republike Hrvatske. Pravilnik o hrani za posebne prehrambene potrebe [Regulation of special nutrition requirements, in Croatian]. Narodne novine 2004/81.

21. Ministarstvo zdravstva i socijalne skrbi Republike Hrvatske. Pravilnik o zdravstvenoj ispravnosti dijetetskih namirnica [Regulation of the health accuracy of food, in Croatian]. Narodne novine 1994/21.

22. U.S. National Research Council and Committee on Dietary Allowances. Recommended Dietary Allowances. Washington (DC): National Academy Press; 1989.

23. Food and Nutrition Board, Institute of Medicine. Dietary Reference Intakes for Energy, Carbohydrate, Fiber, Fat, Fatty Acids, Cholesterol, Protein, and Amino Acids. Washington (DC): National Academy Press; 2002.
24. Walsh JS, Henry YM, Fatayerji D, Eastell R. Lumbar spine peak bone mass and bone turnover in men and women: a longitudinal study. Osteopor Int 2009; 20:355-62.

25. Lu PW, Briody JN, Ogle GD, Morley K, Humphries IRJ, Allen J, Howmangiles R, Sillence D, Cowell CT. Bone mineral density of total body, spine, and femoral neck in children and young adults: a cross-sectional and longitudinal study. J Bone Mineral Res 1994;9:1451-8.

26. Cvijetic S, Colic Baric I, Keser I, Cecic I, Satalic Z, Blanusa M. Peak bone density in Croatian women: Variations at different skeletal sites. J Clin Densitom 2008;27:260-5.

27. Lunt M, Felsenberg D, Adams J, Benevolenskaya L, Cannata J, Dequeker J, Dodenhof C, Falch JA, Johnell O, Khaw KT, Masaryk P, Pols H, Poor G, Reid D, Scheidtnave C, Weber K, Silman AJ, Reeve J. Population-based geographic variations in DXA bone density in Europe: the EVOS study. Osteopor Int 1997;7:175-89.

28. El-hajj Fuleihan G, Baddoura R, Awada H, Salam N, Salamoun M, Rizk P. Low peak bone mineral density in healthy Lebanese subjects. Bone 2002;31:520-8.

29. Henry YM, Fatayerji D, Eastell R. Attainment of peak bone mass at the lumbar spine, femoral neck and radius in men and women: relative contributions of bone size and volumetric bone mineral density. Osteopor Int 2004;15:263-73.

30. Fischer S, Milinarsky A, Giadrosich V, Casanova D. Effects of calcium supplementation on bone density in girls. Revista Med Chile 1999;127:23-7.

31. Matkovic V, Kostial K, Simonovic I, Buzina R, Brodarec A, Nordin BE. Bone status and fracture rates in two regions of Yugoslavia. Am J Clin Nutr 1979;32:540-9.

32. Ilich JZ, Skugor M, Hangartner T, Baoshe A, Matkovic $\mathrm{V}$. Relation of nutrition, body composition and physical activity to skeletal development: a cross-sectional study in preadolescent females. J Am Coll Nutr 1998;17:136-47.

33. Sandler RB, Slemenda CW, LaPorte RE, Cauley JA, Schramm MM, Barresi ML, Kriska AM. Postmenopausal bone density and milk consumption in childhood and adolescence. Am J Clin Nutr 1985;42:270-4.

34. Heaney RP, Weaver CM, Fitzsimmons ML. Soybean phytate content: effect on calcium absorption. Am J Clin Nutr 1991;53:745-7.

35. Barbosa JC, Shultz TD, Filley SJ, Nieman DC. The relationship among adiposity, diet, and hormone concentrations in vegetarian and nonvegetarian postmenopausal women. Am J Clin Nutr 1990;51:798-803.

36. New SA, Bolton-Smith C, Grubb DA, Reid DM. Nutritional influences on bone mineral density: a cross-sectional study in premenopausal women. Am J Clin Nutr 1997;65:1831-9.

37. Yano K, Heilbrun LK, Wasnich RD, Hankin JH, Vogel JM. The relationship between diet and bone mineral content of multiple skeletal sites in elderly Japanese-American men and women living in Hawaii. Am J Clin Nutr 1985;42:877888.

38. Carbone LD, Bush AJ, Barrow KD, Kang AH. The relationship of sodium intake to calcium and sodium excretion and bone mineral density of the hip in postmenopausal African-American and Caucasian women. J Bone Min Metabol 2006;21:415-20.

39. Cirillo M, Ciacci C, Laurenzi M, Mellone M, Mazzacca G, De Santo NG. Salt intake, urinary sodium, and hypercalciuria. Min Electrolyte Metabol 1997;23:265-8. 
40. Ho SC, Chen YM, Woo JLF, Leung SSF, Lam TH, Janus ED. Sodium is the leading dietary factor associated with urinary calcium excretion in Hong Kong Chinese adults. Osteopor Int 2001;12:723-31.

41. Barzel US, Massey LK. Excess dietary protein can adversely affect bone. J Nutr 1998;128:1051-3.

42. Kerstetter JE, Mitnick ME, Gundberg CM, Caseria DM, Ellison AF, Carpenter TO, Insogna KL. Changes in bone turnover in young women consuming different levels of dietary protein. J Clin Endocrinol Metab 1999;84:1052-5.

43. Kerstetter JE, Looker AC, Insogna KL. Low dietary protein and low bone density. Calcif Tissue Int 2000;66:313.

44. Geinoz G, Rapin CH, Rizzoli R, Kraemer R, Buchs B, Slosman D, Michel JP, Bonjour JP. Relationship between bone mineral density and dietary intakes in the elderly. Osteoporos Int 1993;3:242-8

45. Bass S, Delmas P, Pearce G, Hendrich E, Tabensky A, Seeman E. The differing tempo of growth in bone size, mass and density in girls is region-specific. J Clin Invest 1999; 104:795-804.

46. Bradney M, Karlsson MK, Duan Y, Stuckey S, Bass $\mathrm{S}$, Seeman E. Heterogeneity in the growth of the axial and appendicular skeleton in boys: implications for the pathogenesis of bone fragility in men. J Bone Miner Res 2000;15:1871-8. 
Sažetak

\section{RAZLIKE U VRŠNOJ KOŠTANOJ MASI IZMEĐU STUDENTICA I STUDENATA}

Vršna koštana masa važna je odrednica nastanka osteoporotskih prijeloma i poznato je da je veća u muškaraca nego u žena. Cilj istraživanja bio je analizirati razlike u postizanju vršne koštane mase na različitim regijama skeleta između mladih muškaraca i žena. Također je procijenjen utjecaj prehrane i tjelesne aktivnosti na mineralnu gustoću kostiju. Ispitanici su studenti u dobi od 19 do 25 godina, 51 muškog i 75 ženskog spola. Mineralna gustoća kostiju određena je metodom dvoenergetske apsorpciometrije X-zraka na kralježnici, ukupnom femuru i distalnoj trećini radijusa. Podaci o prehrani dobiveni su semikvantitativnim upitnikom o prehrani. Mineralna gustoća kostiju (BMD; $\mathrm{g} \mathrm{cm}^{-2}$ ) bila je veća u studenata na svim mjerenim regijama, dok je procijenjena volumetrijska koštana gustoća (BMAD; $\mathrm{g} \mathrm{cm}^{-3}$ ) bila veća u studentica. U studenata obaju spolova vrijednosti mineralne gustoće kostiju smanjuju se s porastom dobi, jedino se s dobi povećava mineralna gustoća kralježnice u muških studenata. Unos proteina, natrija i vlakana značajno je povezan s koštanom masom. Dobiveni rezultati upućuju na zaključak da muškarci kasnije postižu vršnu koštanu masu, što je najizraženije na kralježnici. U ispitivanoj grupi te se razlike ne mogu objasniti mogućim razlikama u prehrani i/ili tjelesnoj aktivnosti između muških i ženskih ispitanika.

KLJUČNE RIJEČI: mineralna gustoća kosti, mladi ljudi, osteoporoza, prehrana, tjelesna aktivnost

CORRESPONDING AUTHOR:

Selma Cvijetić Avdagić

Institute for Medical Research and Occupational Health

Ksaverska cesta 2, 10001 Zagreb, Croatia

E-mail:scvijetic@imi.hr 